\title{
GEOLOGICAL SURVEY OF FINLAND RADIOCARBON MEASUREMENTS II
}

\author{
E. HYYPP Ä, A. ISOLA, and V. HOFFRÉN \\ $\mathrm{C}^{14}$-Laboratory, Geological Survey of Finland, Otaniemi, Finland
}

The following results represent measurements carried out since our first date list was prepared. Nearly all the dates given were obtained by using two proportional counters. The pretreatment of the samples and the production of pure $\mathrm{CO}_{2}$ followed the method described in Finland I.

\section{SAMPLE DESCRIPTIONS}

\section{GEOLOGIC SAMPLES}

\section{Su-14. Mantsinsaari, NE shore Lake Ladoga}

$\mathbf{8 4 0 0} \pm 250$

6450 в.с.

Carex Equisetum deciduous tree peat (alt 15.3 to $15.4 \mathrm{~m}$ ) from section of drainage channel under embankment, Härkämäki bog, Mantsinsaari $\left(61^{\circ} 22^{\prime}\right.$ N Lat, $31^{\circ} 38^{\prime}$ E Long), USSR. Coll. 1937 by Esa Hyyppä. Comment: pollen analysis places horizon in latter half of Pre-Boreal period (Hyyppä, 1942a, p. 151-156).

\section{Su-15. Kihniö, W Finland $\quad 9850 \pm 320$}

Equisetum-allochthonous peat from Lapaneva peat bog, alt $163 \mathrm{~m}$, Kihnio $\left(62^{\circ} 15^{\prime} \mathrm{N}\right.$ Lat, $23^{\circ} 18^{\prime} \mathrm{E}$ Long). Coll. 1958 by M. Salmi, Geol. Survey of Finland. Comment: according to pollen analysis, horizon represents approximately Pre-Boreal Betula maximum (Salmi, 1963).

\section{Su-16. Koivisto, Karelian Isthmus, USSR \\ $7000 \pm 180$ \\ 5050 в.C.}

Peat from hand-dug section under Littorina sand bar at railroad cut $\mathbb{W}$ of Koivisto railroad station $\left(60^{\circ} 21^{\prime} \mathrm{N}\right.$ Lat, $28^{\circ} 37^{\prime} \mathrm{E}$ Long). Coll. 1935 by Esa Hyyppä. Comment: according to pollen analysis, horizon represents beginning of first Littorina transgression (LI), which is in accord with $\mathrm{C}^{14}$-dating (Hyyppä, 1937).

\section{Su-17. Rovaniemi, southern Finnish Lapland $\quad 4350 \pm 130$ \\ 2400 в.c.}

Sphagnum-Carex peat 1.1 to $1.2 \mathrm{~m}$, alt $91 \mathrm{~m}$, taken with piston drill especially constructed for $\mathrm{C}^{14}$ samples. Mustonlampi bog $\left(66^{\circ} 25^{\prime} \mathrm{N}\right.$ Lat, $23^{\circ}$ 30' E Long), S side of Rovaniemi. Coll. 1958 by Esa Hyyppä. Comment: according to pollen analysis, vigorous spread of spruce began in area at that time, considerably earlier than at Pello (Su-25, $3250 \pm 140$, this date list).

\section{Su-18. Kertteenjärvi lake, Kuorevesi, W Finland}

$4990 \pm 140$

Coarse detritus and remains of wood underlying silt layer ca. $2 \mathrm{~m}$ thick, recording flooding possibly caused by isostatic tilting of lake basin on $\mathrm{N}$ side of Kerttee River ( $62^{\circ} 03^{\prime}$ N Lat, $24^{\circ} 30^{\prime}$ E Long). Coll. by W. Silfversparre 
and Esa Hyyppä. Comment: date represents flooding at end of Atlantic period in region of Näsijärvi chain of lakes.

\section{Su-19. Lake Wanchi near Addis Ababa, Ethiopia $\quad 1400 \pm 140$ \\ A.D. 550}

Wood fragment, $5 \times 5 \times 15 \mathrm{~cm}$, dislodged from upper end of stub of dead tree, probably Juniperus procera, in shorewater of Wanchi crater lake, $65 \mathrm{mi}$ WSW of Addis Ababa ( $8^{\circ} 48^{\prime} \mathrm{N}$ Lat, $37^{\circ} 52^{\prime} \mathrm{E}$ Long). Coll. 1957 by Helmer Smeds. Comment: dead trees rise ca. $3 \mathrm{~m}$ from bottom to surface of lake, which must have risen at least that much. Recent hypothesis of Julius Büdel (1954) seeking to explain changes in other parts of Ethiopia by tectonic and volcanic events-as opposed to former hypotheses relating the changes to alternation of pluvials and interpluvials-seems to be confirmed by dating of present sample.

\section{Su-20. Salmivaara, Salla, $E$ part of southern $\quad \mathbf{8 2 0 0} \pm 250$ Finnish Lapland \\ 6250 в.c.}

Fine-detritus gyttja 4.5 to $4.6 \mathrm{~m}$. Sample series taken with piston drill. Ruokoaapa peat bog ( $66^{\circ} 52^{\prime} \mathrm{N}$ Lat, $28^{\circ} 41^{\prime} \mathrm{E}$ Long), alt 194.4 m. Coll. 1961 by Esa Hyyppä. Comment: according to $\mathrm{C}^{14}$-dating, the Betula time would seem to extend up to Boreal zone in northern Lapland.

\section{$\begin{array}{ll}\text { Su-21. Taivalkoski, } E \text { part of southern } & 8120 \pm 240\end{array}$ Finnish Lapland \\ 6170 в.c.}

Coarse detritus gyttja 4.35 to $4.5 \mathrm{~m}$ Heinälampi peat bog alt $275 \mathrm{~m}\left(65^{\circ}\right.$ 34' N Lat, 28 $8^{\circ} 15^{\prime}$ E Long). Coll. 1961 by Esa Hyyppä, sample series taken with piston drill. Comment: horizon corresponds to upper part of Betula maximum zone, as in preceding bog, whose $\mathrm{C}^{14}$-date is also similar.

\section{Su-22. Pello, 4.6 m, W Finnish Lapland $\quad 5630+160$ 3690 B.C.}

Betula wood $4.6 \mathrm{~m}$, bog on NE side of village of Pello alt $288 \mathrm{~m}\left(66^{\circ} 46^{\prime}\right.$ $N$ Lat, $24^{\circ} 04^{\prime} \mathrm{E}$ Long). Samples taken with piston drill. Coll. 1961 by Esa Hyyppä. Comment: dated horizon belongs to first half of Atlantic.
Su-23.
Pello, $5.5 \mathrm{~m}$
$7400 \pm 190$
$\mathbf{5 4 5 0}$ в.с.

Betula wood $5.5 \mathrm{~m}$. Comment: end of Boreal (Pinus begins decline to Atlantic minimum), which is also in keeping with $\mathrm{C}^{14}$-dating.
Su-24. Pello, $6.3 \mathrm{~m}$
$8150 \pm 210$
6200 в.C.

Betula wood, $6.3 \mathrm{~m}, 20 \mathrm{~cm}$ above bottom, in terrestrial peat. Comment: Betula culminates, Pinus rising toward Boreal maximum, Pinus maximum time did not begin in Pello area, according to $\mathrm{C}^{14}$-dating, until ca. 6000 B.C., as also suggested by Salla (Su-20) and Taivalkoski ( $\mathrm{Su}-21)$.

\section{Su-25. Pello, 84-m bog \\ $3250 \pm 140$ \\ 1300 в.C.}

Carex-Sphagnum peat in a lower-lying bog in Pello 1.2 to $1.3 \mathrm{~m}$, surface alt $84 \mathrm{~m}$ Tornio River valley ( $66^{\circ} 46^{\prime} \mathrm{N}$ Lat, $24^{\circ} 04^{\prime} \mathrm{E}$ Long). Coll. 1955 by Esa Hyyppä. Comment: dating made from same horizon as Su-10 (4700 \pm 
100, Finland I), which seemed to give too great an age for general spread of

Picea in Pello area.

Date list:

\section{REFERENCES}

Finland I Hyyppä, Hoffrén and Isola, 1962

Büdel, Julius, 1954, Results of investigations into climatically controlled landforms carried out in Ethiopia during spring 1953: Erdkunde, v. 8, no. 2, p. 139-156.

Hyyppä, Esa, 1936, Über die Spätquartäre Entwicklung Nord-Finnlands mit Ergänzungen zur Kenntnis des spätglazialen Klimas: C. R. Soc. Géol. Finl. no. 9, p. 402-465.

1937, Post-Glacial changes of shore line in South Finland: Bull. Comm. Géol. Finl. no. 120, p. 1-225.

1942a, Beiträge zur Kenntnis der Ladoga-und Ancylustransgression: C. R. Soc. Géol. Finl. no. 15, p. 137-177.

Hyyppä, E., Hoffrén, V., Isola, A., 1962, Geological Survey of Finland Radiocarbon Measurements I: Radiocarbon, v. 4, p. 81-83.

Salmi, Martti, 1963, Radiocarbon determinations from the bog profile of Lapaneva, Kihniö, Western Finland: C. R. Soc. Géol. Finl. no. 34, 8.

Unpublished report, Geological Survey of Finland (in the Archives of the Dept. of Surficial Deposits). 